U. S. DEPARTMENT OF COMMERCE BUREAU OF STANDARDS

\title{
COTTON CLOTH FOR RUBBER AND PYROXYLIN COATING
}

COMMERCIAL STANDARD CS32-31

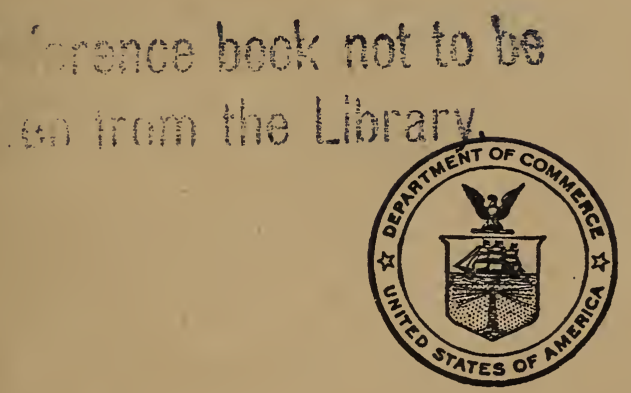

A RECORDED STANDARD OF THE INDUSTRY 
Below are described some of the series of publications of the Department of Commerce which deal with various phases of waste elimination.

\section{Simplified Practice Recommendations.}

These present in detail the development of programs to eliminate unnecessary variety in sizes, dimensions, styles, and types of over 120 commodities. They also contain lists of associations and individuals who have indicated their intention to adhere to the recommendations. These simplified schedules, as formulated and approved by the industries, are indorsed by the Department of Commerce.

American Marine Standards.

These are promulgated by the American Marine Standards Committee, which is controlled by the marine industry and administered as a unit of the division of simplified practce. Their object is to promote economy in construction, equipment, maintenance, and operation of ships. In general, they provide for simplification and improvement of design, interchangeability of parts, and minimum requisites of quality for efficient and safe operation.

\section{Commercial Standards.}

These are developed by various industries under a procedure similar to that of simplified practice recommendations. They are, however, primarily concerned with considerations of grade, quality, and such other characteristics as are outside the scope of dimensional simplification.

Lists of the publications in each of the above series can be obtained by applying to the Bureau of Standards, Washington, D. C. 
U. S. DEPARTMENT OF COMMERCE

R. P. LAMONT, Secretary

BUREAU OF STANDARDS

GEORGE K. BURGESS, Director

\title{
COTTON CLOTH FOR RUBBER AND PYROXYLIN COATING
}

\section{COMMERCIAL STANDARD CS32-31}

\author{
Effective Date for New Production \\ and Clearance of Existing Stocks \\ June 15, 1931
}

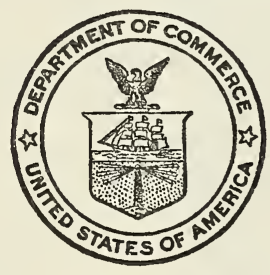

UNITED STATES

GOVERNMENT PRINTING OFFICE WASHINGTON : 1931 


\section{CONTENTS}

Acceptors

Commercial standard

Scope.

General requirements

Detail requirements . . .

Methods of testing

Cooperating organizations and firms

Standing committee.

Effective date

Certification plan

Commercial-standards service.

Organization and duties of standing committee

Your cooperation

Acceptance of commercial standard

To the acceptor 


\section{COTTON CLOTH FOR RUBBER AND PYROXYLIN COATING}

\section{ACCEPTORS}

\section{ASSOCIATIONS}

Association of Pyroxylin Coated Fabric Manufacturers, New York, N. Y.

National Association of Purchasing Agents, New York, N. Y.

National Council of the Y. M. C. A. of U. S. A., New York, N. Y.

New England Council, Boston, Mass. (in principle).

FIRMS

Aetna Rubber Co., Boston, Mass. (in principle).

Athol Manufacturing Co., Athol, Mass.

Bancroft \& Sons Co., Joseph, Wilmington, Del.

Barnard Manufacturing Co., Fall River, Mass.

Boston Woven Hose \& Rubber Co., Cambridge, Mass.

Brookside Mills, Knoxville, Tenn.

Buckeye Fabric Finishing Co., The, Coshocton, Ohio.

Callaway Mills (Inc.), New York, N. Y.

Cannon Mills (Inc.), New York, N. Y.

Carpenter \& Co., L. E., Newark, N. J.

Certified Silk Service (Inc.), New York, N. Y. (in principle).

Columbia Mills (Inc.), The, New York, N. Y.

Converse Rubber Co., Malden, Mass.

Cotex Corporation, Nervark, N. J.

Crescent Specialty Co., Chicago, Ill.

Crown Cotton Mills, Dalton, Ga.

Dallas Manufacturing Co., The, Huntsville, Ala.

De Luxe Mills (Inc.), Philadelphia, Pa.

du Pont de Nemours \& Co. (Inc.), E. I., Fairfield, Conn.

du Pont de Nemours \& Co. (Inc.), E. I., Newburgh, N. Y.

Exposition Cotton Mills, Atlanta, Ga. Federal Leather Co., The, Belleville, N. J.

Fine Rubber Co., The, Malden, Mass. Fitchburg Duck Mills, Fitchburg, Mass.

Griswoldville Manufacturing Co., Griswoldville, Mass. (in principle).
Gross Co., Wm. M.. Sharon, Pa.

Haartz Co.. J. C., New Haven, Conn.

Haartz-Mason-Grower Co., Watertown, Mass.

Harrington, King \& Co., Boston, Mass.

Hodgman Rubber Co., Framingham, Mass.

Holliston Mills (Inc.), The, Norwood, Mass.

Hunter Manufacturing \& Commission Co., New York, N. Y.

Hydrex Asphalt Products Corporation, New York, N. Y. (in principle).

Landers Corporation, The, Toledo, Ohio.

Lane \& Co., J. H., New York, N. Y.

Lederer Manufacturing Co., Detroit, Mich.

Lombard Manufacturing Co., St. Louis, Mo.

Lullwater Manufacturing Co., The, Thomson, Ga.

Macy \& Co. (Inc.), R. H., New York, N. Y.

Manville Jenckes Co., Pawtucket, R. I.

Marathon Rubber Products (Inc.), Wausau, Wis.

Masland Duraleather Co., The, Philadelphia, $\mathrm{Pa}$.

Moultrie Cotton Mills, Moultrie, Ga.

Mount Vernon-Woodberry Mills (Inc.), Baltimore, Md.

OMO Manufacturing Co., Middletown, Conn.

Permatex Fabrics Co., division of The Aspinook Co., Jewett City, Conn.

Pocono Rubber Cloth Co., The, Trenton, N. J.

Rand Rubber Co., Brooklyn, N. Y.

Rhodhiss Mills Co., Rhodhiss, N. C.

Riverdale Mills, Spartanburg, S. C.

St. Clair Rubber Co., Marysville, Mich.

Santee Mills, Orangeburg, S. C.

Schwab \& Wolf, New York, N. Y. (in principle).

Scottdale Mills, Scottdale, Ga.

South Texas Cotton Mills, Brenham, Tex.

Sperry Flour Co., San Francisco, Calif. (in principle).

Stein \& Co., A., Chicago, Ill. 
Sterens \& Co. (Inc.), J. P., New York, N. Y.

Textileather Corporation, Toledo, Ohio. Turner Halsey Co., New York, N. Y.

Universal Hospital Supply Co., Chicago, IIl.

U. S. Rubber Co., Orange, N. J.

Van Cleef Bros., Chicago, Ill.

Wellington Sears Co., New York, N. Y.

Western Shade Cloth Co., The, Chicago, IIl.

West Point Manufacturing Co., West Point, Ga.

Weymouth Art Leather Co. (Inc.), East Weymouth, Mass.
Worcester Backing Co. (Inc.), Worcester, Mass.

Zapon Co., Stamford, Conn.

GOVERNMENT

Department of Agriculture, U. S. Bureau of Home Economics, Division of Textiles and Clothing, Washington, D. C. (in principle).

Post Office Department, Washington, D. C.

U. S. Treasury Department, Washington, D. C. 


\title{
COTTON CLOTH FOR RUBBER AND PYROXYLIN COATING
}

\author{
COMMERCIAL STANDARD CS32-31
}

Pursuant to a request from the Cotton-Textile Institute (Inc.), and with the approval of the Association of Cotton Textile Merchants of New York, The Association of Pyroxylin Coated Fabric Manufacturers, and the Automotive Fabric Manufacturers Division of the Rubber Manufacturers Association (Inc.), the Department of Commerce submitted to the industry on February 20, 1931, for acceptance, a recommended commercial standard for cotton cloth for rubber and pyroxylin coating. The industry has since accepted and approved for promulgation by the Department of Commerce, through the Bureau of Standards, the standard shown herein.

This recommendation became effective for new production and clearance of existing stocks on June 15, 1931.

Promulgation recommended.

Promulgated.

I. J. FATRCHILD, Chief, Division of Trade Standards.

APPROVED.

George K. Burgess, Director, Bureau of Standards.

R. P. LAMONT, Secretary of Commerce. 


\section{COMMERCIAL STANDARD CS32-31}

This standard is practically identical in content with the Standard Specifications and Tests for Cotton Goods for Rubber and Pyroxylin Coating published on June 18, 1930, by the Association of Cotton Textile Merchants of New York, the Cotton-Textile Institute (Inc.), Association of Pyroxylin Coated Fabric Manufacturers, and the Automobile Fabric Manufacturers Division of the Rubber Manufacturers Association (Inc.). It is identical in content with the Proposed Tentative Specification and Test Methods for Cotton Goods for Rubber and Pyroxylin, Coating of the American Society for Testing Materials (A. S. T. M. designation D334-31).

\section{SCOPE}

This commercial standard covers the construction, quality, sizing, methods of test, and labeling of cotton cloth for rubber and pyroxylin coating.

\section{GENERAL REQUIREMENTS}

\section{QUALITY}

The cloth shall be made of cotton thoroughly cleaned and carded, free from waste, and shall be of good commercial quality, evenly woven.

\section{WIDTH}

The width of the cloth shall not vary more than plus or minus 1.5 per cent from the specified width.

\section{COUNT}

The count of the cloth shall not vary more than plus or minus 2 per cent in the warp and 5 per cent in the filling from the specified count. The variation in count in a shipment shall not exceed 1 per cent in the warp and 3 per cent in the filling.

\section{UNIT WEIGHT}

The unit weight shall be expressed in linear yards of the fabric per pound and shall be determined from the invoiced yardage and the weight of the entire roll or piece (both verified when necessary). Such weight shall be as specified for the fabric in question, with a minus tolerance of 1 per cent on a shipment, $21 / 2$ per cent on a roll, and 5 per cent on a piece, from the specified weight.

\section{DETAII REQUIREMENTS}

\section{SIZING}

As little sizing shall be used in the fabric as is necessary for its proper manufacture. The total percentage of sizing, natural oils, 
and waxes shall be no more than is shown below for each type of fabric.

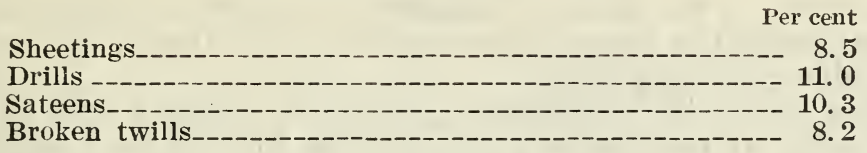

INJURIOUS CHEMICALS

It shall be recognized that the chemicals listed below are injurious to rubber, and, in so far as they come under the control of the mill, the quantity shall not exceed the following percentages:

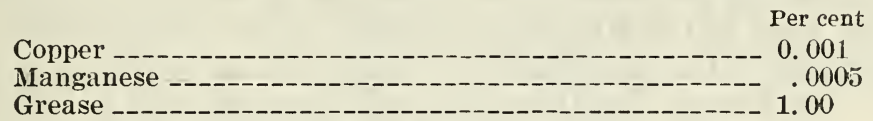

TENSILE STRENGTH

The specified tensile strength shall conform to the requirements given in Table 1. In the case of constructions not pro rata to any of those listed in Table 1, the strength shall be agreed upon when the contract is placed.

TABLE 1.-Tensile strength

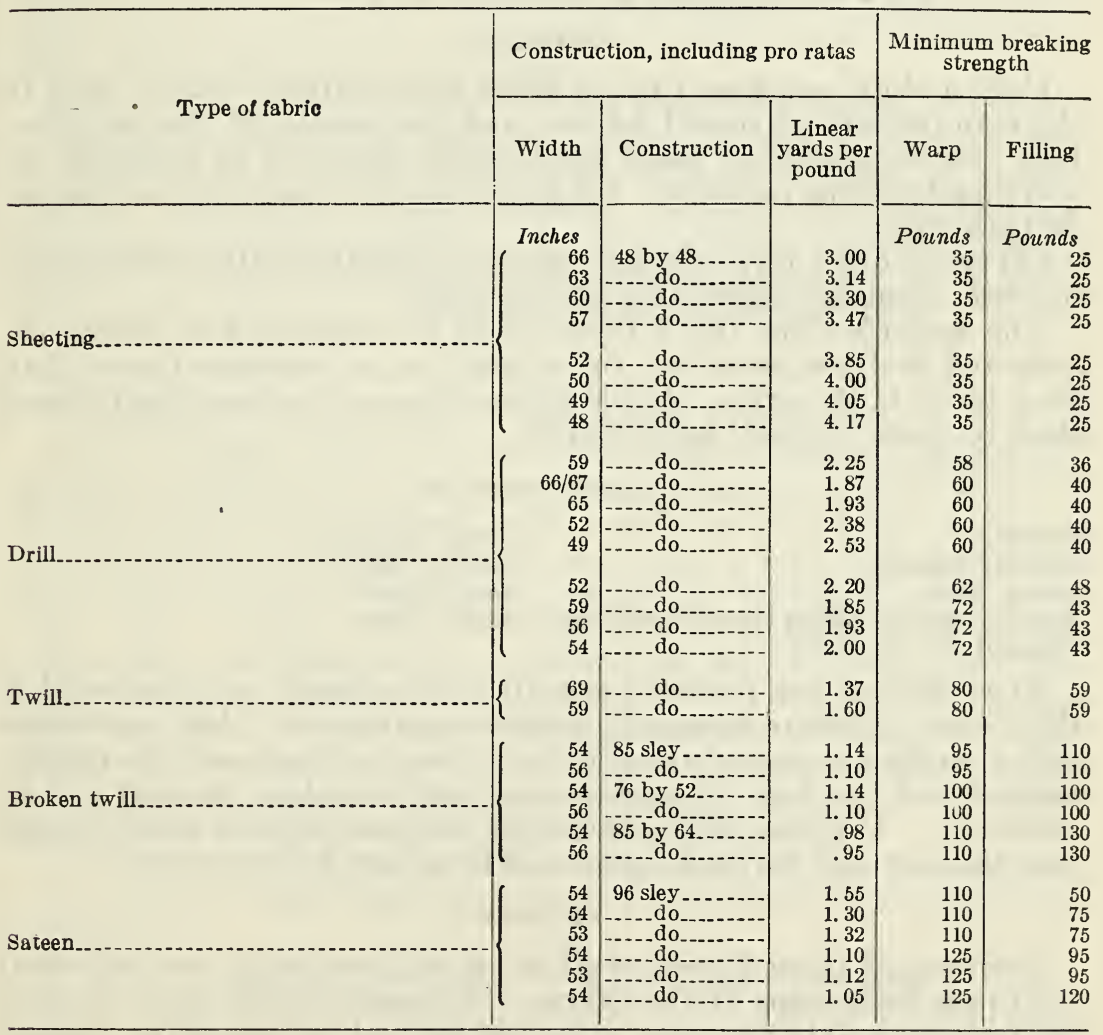




\section{LENGTH OF CUTS}

Sheetings.-Two classes of delivery in respect to length of piece may be specified in the purchase contract: (1) Double cuts as far as practicable; (2) long cuts.

Double cuts.- In classification known as "double cuts as far as practicable," 10 per cent of pieces in from 40 to 80 yard lengths will be accepted at the contract price, the balance to be in pieces not less than 80 yards in length.

Long cuts.-The designation of long cuts of sheetings shall require an average length of piece of 250 yards with a minimum of 200 yards, supplier having the privilege of applying up to 10 per cent if made of pieces from 100 to 200 yards in length at the contract price.

1. Drills.-The designation of long cuts of drills shall require an average length of piece of 175 yards with a minimum of 120 yards, supplier having the privilege of applying up to 10 per cent if made of pieces from 60 to 120 yards in length at the contract price.

2. Sateens, broken twills, and moleskins.-The designation of long cuts of sateens, broken twills, and moleskins shall require a minimum length of 120 yards, supplier having the privilege of applying not more than one 60-yard piece for 500 yards shipped at the contract price.

\section{DEFECTS}

Cotton cloth purchased under these specifications will be used in the manufacture of coated fabrics, and the vendor, in the manufacture and inspection of these goods, shall endeavor to meet the requirements of this industry. All fabrics shall be inspected and burled on both sides.

Oil spots, holes, torn selvages, and warp streaks shall not be present in cloth furnished under this specification.

The imperfections listed below shall be recognized as major defects and shall not occur in a roll of cloth on an average of more than once in each 15 yards. A minimum allowance of one-fourth yard shall be made for each major defect.

\section{MAJOR DEFECTS}

Smash.

Starchy places.

Group float.

Two contiguous filling threads missing.

Washed-out oil spots.
Heavy filling.

Shuttle mark.

Heavy warp.

Kinky filling.

These defects are probably not all which should be listed, so that this list is subject to change by common agreement. Also one major defect on the average of every 15 yards does not represent the quality desired, but has been suggested as a fair basis both to mill and to consumer. The aim of the mills will be so to improve their quality that this average yardage between defects may be increased.

\section{SELVAGE}

Selvages of these fabrics shall be of uniform width and of equal width on both edges of the fabric. Selvages shall be so made that the tension shall be the same as that of the body of the cloth. Baggy goods and curling selvages shall be cause for rejection. 


\section{METHODS OF TESTING}

\section{WIDTH}

The width of the fabric in any roll or piece shall be determined by laying the fabric on a flat surface under no tension, with wrinkles removed, and measuring the width perpendicular to the selvage at five different places evenly distributed through the roll or piece. The average of these five measurements shall be considered the actual width.

\section{COUNT}

The count of the fabric in any roll or piece shall be determined by counting a space of not less than 1 inch in at least five different places in the roll or piece without duplicating the determination on any one set of threads. The average of these five or more determinations in the warp and filling shall be the count.

\section{TENSILE STRENGTH}

The average of five determinations in the direction of the warp and five in the direction of the filling shall be not less than the specified tensile strength for warp and filling, respectively.

The tensile strength shall be determined by the 1 by 1 by 3 inch grab test in accordance with sections 11 and 12 of the Standard General Methods of Testing Woven Textile Fabrics (A. S. T. M. designation D39) of the American Society for Testing Materials and shall conform to the following requirements:

The back half of each pair of jaws shall be 2 inches or more in width and the front half shall be 1 inch in width. The jaws shall be planed smooth and flat with edges slightly rounded to prevent cutting. The initial distance between the jaws of the testing machine shall be 3 inches and the pulling jaws shall travel at a uniform rate of 12 inches per minute. Test pieces shall be 6 by 4 inches wide, and no two test pieces shall include the same threads.

\section{SIZING}

The amount of sizing shall be determined as follows:

1. Cut 1 square foot of fabric and dry to a constant weight in a ventilated drying oven maintained at a temperature of $220^{\circ}$ to $230^{\circ} \mathrm{F}$. Weigh samples from time to time, and when two such weighings, not less than 10 minutes apart, do not show a loss more than 1 per cent of the previous weight, the material is considered to be bonedry. These weights may be obtained in a conditioning or drying oven with a weighing device mounted on top in such a way that samples may be weighed while they are in the oven; or, if no such weighing device is available, the samples may be taken from the oven and very quickly inserted in a glass capsule or bottle with an air-tight glass stopper. The bottle, with the samples, may then be weighed and the tare weight of the bottle subtracted.

2. Boil for 30 minutes in a one-half of 1 per cent hydrochloric acid solution. This solution is to be boiling before the samples are placed in it.

3. Remove samples and rinse thoroughly in clear water.

4. Boil the samples for 30 minutes in a 1 per cent solution of sodium carbonate; the solution is to be boiling before the samples are placed in it. 
5. Remove samples and rinse thoroughly in clear water.

6. Obtain bone-dry weight as described in 1 .

7. Calculation.-Calculate the percentage loss in weight from the results obtained in paragraphs 1 and 6 and subtract 3.2 per cent as an allowance for the extracted weight of oil, waxes, and other foreign matters; the difference arrived at is considered to be the percentage of size.

In arriving at the average of 3.2 per cent above, many tests were made in the following manner: By cutting 1 yard of yarn from beam before it entered slasher and then cutting a 1-yard sample of the sized yarn and also a 1-yard sample of cloth from the loom, and boiling them in same process; the actual average is 3.2 per cent, the low being 2.63 per cent and the high 3.85 per cent.

\section{COOPERATING ORGANIZATIONS AND FIRMS}

The organizations actively cooperating in the standardization of cotton cloth for rubber and pyroxylin coating are: The Association of Cotton Textile Merchants of New York, The Cotton Textile Institute (Inc.), Association of Pyroxylin Coated Fabric Manufacturers, and Automobile Fabric Manufacturers Division of The Rubber Manufacturers Association (Inc.).

Prior to the publication of these specifications by the Association of Cotton Textile Merchants of New York the following firms indicated their approval:

Through The Association of Cotton Textile Merchants of New York:

Callaway Mills (Inc.).

Cannon Mills (Inc.).

Catlin-Farish Co.

Consolidated Selling Co. (Inc.).

Hesslein \& Co. (Inc.).

Hunter Mfg. \& Commission Co.
J. H. Lane \& Co.

Minot, Hooper \& Co.

J. P. Stevens \& Co. (Inc.).

Turner, Halsey Co.

Wellington, Sears \& Co.

Through the Cotton-Textile Institute (Inc.):

The cotton mills represented by the above-mentioned 11 firms.

Through the Association of Pyroxylin Coated Fabric Manufacturers:

Aspinook Co.

Athol Co.

L. E. Carpenter Co.

F. S. Carr Co.

L. C. Chase \& Co.

Sanford Mills.

Coated Textile Mills (Inc.).

E. I. du Pont de Nemours \& Co. (Inc.).
Federal Leather Co.

Masland Duraleather Co.

Pantasote Leather Co.

Standard Textile Products Co.

Textileather Corporation.

Western Shade Cloth Co.

Weymouth Art Leather Co.

Zapon Co.

Richards \& Co.

Through the Automobile Fabric Manufacturers Division of The Rubber Manufacturers Association (Inc.):

Boston Woven Hose \& Rubber Co.

F. S. Carr Co.

Cotex Corporation.

L. C. Chase \& Co.

Reading Rubber Mfg. Co.

E. I. du Pont de Nemours \& Co. (Inc.).
J. C. Haartz Co.

Landers Corporation.

Pocono Rubber Cloth Co.

St. Clair Rubber Co.

United States Rubber Co.

Zapon Co.

Richards \& Co.

Since the work of the several associations has paralleled commercial standards procedure to a certain extent, no general conference was deemed necessary. 


\section{STANDING COMMITTEE}

The following individuals were appointed to represent the various interests of the industry and to receive all comments and suggestions for the improvement of the commercial standard:

R. E. Benson, Jr., chairman, Hunter Manufacturing \& Commission Co.

L. R. BaIley, E. I. du Pont de Nemours \& Co. (Inc.).

C. Stewart Comeaux, secretary, Association of Pyroxylin Coated Fabric Manufacturers.

J. R. CORLEY, Wellington, Sears \& Co.

H. H. Barnard, Callaway Mills.

GEorge Flint, assistant secretary, Rubber Manufacturers Association (Inc.).

H. S. Johnson, Cotton-Textile Institute (Inc.).

P. S. Newell, Cotton Textile Merchants of New York.

\section{EFFECTIVE DATE}

The effective date for the production and sale of cotton cloth for rubber and pyroxylin coating under the commercial standard was set for June 15, 1931.

\section{CERTIFICATION PLAN}

On recommendation of the Cotton-Textile Institute (Inc.), the "certification plan" will be applied to this standard.

The certification plan as applied by the Bureau of Standards to commercial standards consists in the compilation and distribution of lists of manufacturers who are willing, when requested to do so, to certify to purchasers that products supplied by them comply with all the requirements and tests set forth in nationally recognized commercial standards. The plan is also applied to selected Federal specifications.

These lists are available on request to individual consumers, consumer groups, companies, and, in fact, to any prospective purchasers for their guidance.

The benefits now derived from the use of specifications by large consumers are thus made immediately available to the small consumer, with incidental advantage to the larger consumers of convenience in ordering and accepting material with fewer laboratory tests. The manufacturer also benefits from the well-known economies accompanying "mass production."

The lists of manufacturers "willing to certify" to the quality of certain commodities are made by corresponding with, as nearly as possible, all the manufacturers of that product and listing only those who signify their willingness to certify to the purchaser, when requested to do so, that the commodities delivered actually comply with the commercial standard.

Obviously, the purchaser making use of the lists of "willing-tocertify" manufacturers will select therefrom such manufacturers as are known (or assumed) by him to be reliable.

The trend toward the purchase of materials of certified quality from sources shown on such willing-to-certify lists supplies added incentive to standardization on the part of other producers, and thus the benefits of the certification plan will be felt by purchasers either directly or indirectly, whether or not they make use of the plan themselves. 


\section{COMMERCIAL STANDARDS SERVICE}

Industry has long sensed the need for a wider application and use of specifications developed and approved by nationally recognized organizations. To assist these bodies and the producers and consumers in securing this result and as a natural outgrowth of the movement toward elimination of waste through simplified practice, the Bureau of Standards has set up a procedure under which specifications, properly indorsed, may be printed as official publications of the Department of Commerce and promulgated as "Commercial Standards." This service parallels that of simplified practice in many respects and is available only upon request.

Bropadly speaking, the aim is to continue the same character of cooperative service in this field that is being rendered in simplification. The division of trade standards is not designated to act as a standardizing body, nor will it engage in the preparation of specifications. Its service is mainly promotional in character, since its chief mission is to invite attention to a standard or a specification which any branch of industry may want to promulgate on a nationwide basis; to determine its eligibility for promulgation; to publish and broadcast it in the event the prerequisites of procedure have been met, including a satisfactory majority acceptance; to facilitate the application of the certification plan for the assurance and convenience of the purchaser; to provide means for periodic audits of adherence; and to cooperate with the Bureau of Foreign and Domestic Commerce in determining the desire of industry relative to translation and promulgation of such specifications as a basis for foreign commerce.

In general, it may be said that a simplification covers types, sizes, and varieties of a commodity which are retained by industry on the basis of demand, whereas a commercial standard establishes definite requirements as to grade, quality, or dimensional tolerances in addition to any limitation of variety desired and accepted by the industry.

\section{ORGANIZATION AND DUTIES OF STANDING COMMITTEE}

In order to carry on the aims and desires of the industry in the standardization of their product, a standing committee is appointed at the general conference. This committee consists of members from each division of the industry, namely, producers, distributors, and consumers, and thus reflects the well-balanced viewpoint of all concerned.

The members of the committee receive all suggestions regarding the commercial standard and consider its revision in the event that such action is desirable and mutually beneficial.

If the commercial standard does not warrant revision, it is reaffirmed in its existing form, but if any important changes are found desirable, their adoption is recommended by the committee, whereupon the industry is again solicited for written acceptance of the standard in its revised form.

The committee is, in effect, a centralizing agency for criticisms and comments regarding the commercial standard and is charged with the responsibility of recommending revisions to keep the standard abreast with current industrial practice. 
The proper functioning of the committee requires that, when necessary, its members be willing to attend meetings held at some central place, although in many cases it will be possible to conduct the work by correspondence.

When any deceptions in reference to the commercial standard are reported to the standing committee, it applies moral suasion or such other corrective measures as seem desirable. The Department of Commerce has no "police power" to compel adherence; therefore it is incumbent upon the standing committee to do all in its power to encourage all divisions of the industry to follow the provisions of the commercial stanclard and contribute in every way possible to its general adoption and usefulness.

\section{YOUR COOPERATION}

As a producer, distributor, or consumer of some of the commodities for which commercial standards have already been established, you are in a position to avail yourself of the benefits arising from the use of quality standards and incidentally to add impetus to this method of eliminating waste.

The first step is a declaration in favor of the standard by recording your intention to adhere, as closely as circumstances will allow, to the standards for those products which you may buy or sell.

The receipt of your signed acceptance will permit the listing of your company in new editions of the commercial standards that you accept.

You will, of course, want to examine any commercial standards before signing a formal acceptance. The Bureau of Standards will therefore furnish a copy of any standard under consideration for acceptance. A list of current commercial standards is given on the rear cover.

The publications may also be secured singly or in quantities at a nominal price from the Government Printing Office. Prices will be furnished upon request.

The acceptance of a commercial standard is an entirely voluntary action and applies to the production, sale, and use of stock items. It is not meant to interfere with the introduction, manufacture, or sale of special sizes and types sometimes required.

Trade associations and individual companies often distribute large numbers of the printed standard for the information and guidance of their members or customers. In such cases it is possible to extend the scope and degree of adherence by urging each recipient to send in an acceptance, bearing in mind that the practical value of any standardization is measured by the observance it receives.

An acceptance form for the commercial standard herein covered is included on page 13 . 



\section{ACCEPTANCE OF COMMERCIAL STANDARD}

Please Sign and Return This Sheet to Division of Trade Standards, Bureau of Standards, Washington, D. C.

Date

Division of Trade Standards,

\section{Bureau of Standards,}

$$
\text { Washington, D.C. }
$$

Gentlemen: We, the undersigned, do hereby accept the original draft of the commercial standard as our standard practice in the $\left\{\begin{array}{l}\text { production }^{1} \\ \text { distribution }^{1} \\ \text { use }^{1}\end{array}\right\}$ of cotton cloth for rubber and pyroxylin coating, beginning use our best effort in securing its general adoption.

To permit intelligent review of the effectiveness of the commercial standard every year by an accredited committee of all interests, working in cooperation with the Department of Commerce, we plan to supply all data, upon request, which may be necessary for the development of constructive revisions. It is understood that any suggested modifications will be submitted as soon as formulated, and shall not be promulgated until accepted in form similar to this recommendation.

Signature

[Kindly typewrite or print the following lines.]

Title

Company

Street address

City and State

We are members of the following associations or other organizations interested in the production, sale, or use of cotton cloth for rubber and pyroxylin coating:

1 Please designate which group you represent by drawing lines through the other two. In the case of related interests, trade papers, colleges, etc., desiring to record their general approval, the words "in principle" should be added after the signature. 


\section{TO THE ACCEPTOR}

In signing the acceptance blank please bear the following points clearly in mind:

1. Adherence.-The Department of Commerce has no regulatory powers to enforce adherence to the commercial standards. Instead, this waste-elimination program is based on voluntary cooperation and self-government in industry. To make this specific standardization operate as a satisfactory example of self-government it is highly desirable that it be kept distinct from any plan or method of governmental regulation or control. It will be successful according to the degree to which manufacturers, distributors, and purchasers adhere to its terms and conditions.

2. The industry's responsibility.-The department cooperates only on the request of the industry and assumes no responsibility for industrial acceptance or adherence. This program was developed by the industry on its own initiative. Its success depends wholly on the active cooperation of those concerned.

3. The acceptor's responsibility.- You are entering into an entirely voluntary arrangement whereby the members of the industry-the distributors and consumers of the product and others concernedhope to secure the benefits inherent in commercial standardization. Those responsible for this standard realize that instances may occur in which it will be necessary to supply or purchase items not included therein. The purpose is, however, to secure wider support for nationally recognized standards covering grade, quality, and other characteristics of products. Consumers can make the program a success if in their purchasing they will make a definite and conscientious effort to specify in terms of this commercial standard.

4. The department's responsibility.-The function performed by the Department of Commerce is fourfold: First, to act as a referee to insure adequate consideration of the needs of all interests; second, to supply such assistance and advice in the development of this program as past experience with similar programs may suggest; third, to solicit and record the extent of adoption and adherence to the standard; and, fourth, to add all possible prestige to this standardization movement by publication and promulgation if and when it is adopted and accepted by all elements directly concerned. 


\section{COMMERCIAL STANDARDS}

CS No.

$0-30$. The commercial standards service and its value to business.

1-28. Clinical thermometers.

2-30. Mopsticks.

3-28. Stoddard solvent.

4-29. Staple porcelain (all-clay) plumbing fixtures.

5-29. Steel pipe nipples.

6-31. Wrought-iron pipe nipples (first revision).

7-29. Standard weight malleable iron or steel screwed unions.

8-30. Plain and thread plug and ring gage blanks.

9-29. Builders' template hardware.

10-29. Brass pipe nipples.

11-29. Regain of mercerized cotton yarns.

12-29. Domestic and industrial fuel oils.

13-30. Dress patterns.

14-31. Boys' blouses, button-on waists,

15-29. MTen's pajamas.

16-29. Wall paper

17-30. Diamond core drill fittings.

18-29. Hickory golf shafts.

NoTICE.-Those interested in commercial standards with a view toward accepting them as a basis of everyday practice in their industry may secure copies of the above standards, while the supply lasts, by addressing the Division of Trade Standards, Bureau of Standards, Washington, D. C.
CS No. Item

20-30. Staple vitreous china plumbing fixtures.

21-30. Interchangeable ground glass joints.

22-30. Builders' hardware (nontemplate).

23-30. Feldspar.

25-30. Special screw threads.

26-30. Aromatic red cedar closet lining.

27-30. Plate glass mirrors.

28-32. Cotton fabric tents, tarpaulins, and covers.

29-31. Staple seats for water-closet bowls.

30-31. Colors for sanitary ware.

31-31. Red cedar shingles.

32-31. Cotton cloth for rubber and pyroxylin coating.

33-32. Knit underwear (exclusive of rayon) (in preparation).

34-31. Bag, case, and strap leather.

35-31. Plywood.

36-31. Fourdrinier wire cloth (in preparation).

37-31. Steel bone plates and screws (in preparation).
24-30. Standard screw threads. 
